\title{
Incidence, Transmissibility, and Genotype Analysis of Citrus tristeza virus (CTV) Isolates from CTV Eradicative and Noneradicative Districts in Central California
}

\author{
R. K. Yokomi, and R. L. DeBorde, United States Department of Agriculture-Agricultural Research Service, San \\ Joaquin Valley Agricultural Sciences Center; Crop Diseases, Pests and Genetics Research Unit, Parlier, CA 93648
}

\begin{abstract}
Yokomi, R. K., and DeBorde, R. L. 2005. Incidence, transmissibility, and genotype analysis of Citrus tristeza virus (CTV) isolates from CTV eradicative and noneradicative districts in central California. Plant Dis. 89:859-866.

Growers in $45 \%(44,100$ ha) of the citrus acreage in California stopped eradicating Citrus tristeza virus (CTV)-infected trees from their fields in 1995-96. The impact of leaving infected trees on the rate of CTV spread was determined by comparing temporal incidence of CTV in plots in Strathmore, Tulare County without eradication with incidence in a plot in McFarland, Kern County with eradication. From 1997 to 2003, CTV incidence in the Strathmore plots ranged from 6 to $42 \%$, with annual spread rates from 1.6 to $3.6 \%$. CTV incidence in the McFarland plot increased from 0 to 5\% between 2001 and 2003 before infected trees were removed. Using a subplot hierarchical bulk sampling method, virus incidence over a 3-year period in a $6.5 \mathrm{~km}^{2}$ area near McFarland was estimated to range from 0.09 to $0.69 \%$, which indicated that CTV suppression was still being achieved in this area. Vector tests using the cotton aphid, Aphis gossypii, identified highly transmissible isolates (30 to 61\% transmission rate) and a larger proportion of highly transmissible isolates were found in the McFarland plots. Thirty-six CTV isolates from recently infected plot trees were obtained and analyzed. None of these isolates reacted with monoclonal antibody MCA13 that detects presumptive CTV severe strains. Molecular analysis using polymerase chain reaction and sequence-specific primers showed that all isolates had a genotype identical to the T30 mild isolate from Florida.
\end{abstract}

Additional keywords: aphid transmission

Citrus tristeza virus (CTV) is a positive sense, single-stranded RNA virus (family Closteroviridae, genus Closterovirus) that exists in infected trees as a population of genetic variants that can differ markedly, such as a quasi species (25). The virus is transmitted by aphids in a semipersistent manner most efficiently by the brown citrus aphid, Toxoptera citricida (Kirkaldy) (32,39). In the New World, T. citricida occurs throughout South and Central America, the Caribbean Basin, southeast Mexico (Vera Cruz to Yucatan), Hawaii, and Florida, but does not occur in California, Arizona, or Texas.

In California, CTV first was described by Halma et al. (20) as a destructive malady called citrus quick decline that was associated with sour orange rootstock. Fawcett and Wallace (10) demonstrated that the causal agent was a virus and Schneider (35) found that tree decline and collapse was due to bud union necrosis at

Corresponding author: R. K. Yokomi

Email: ryokomi@fresno.ars.usda.gov

Accepted for publication 5 April 2005.

DOI: 10.1094/PD-89-0859

This article is in the public domain and not copyrightable. It may be freely reprinted with customary crediting of the source. The American Phytopathological Society, 2005. the interface of the scion and the sour orange rootstock. Dickson et al. (6,7) reported that quick decline was vectored by the melon aphid, Aphis gossypii Glover, in an extremely inefficient manner. Martinez and Wallace (27) later reported that three seedling yellows CTV isolates were transmissible by the melon aphid at a rate of 25 , 25 , and $78 \%$ using small replicate sizes per isolate of 4, 16, and 9 plants, respectively. Subsequently, Calavan et al. (3) reported rapid natural spread of seedling yellows and stem pitting CTV isolates in citrus plantings at the University of California at Riverside. High transmission rates by the melon aphid later were confirmed by Roistacher et al. (34), who examined 16 California CTV isolates that included three isolates from central California (T-505, T514, and T-515). They found no differences in ability of cultures of A. gossypii from southern California (Blythe and Brawley cultures) and central California (Tulare culture) to transmit CTV. In Israel, Bar-Joseph and Loebenstein (1) also found no differences in the ability to transmit CTV using A. gossypii collected from citrus or cucumber.

CTV control in central California has been achieved by planting virus-free citrus on CTV-tolerant or -resistant rootstocks, together with the eradication of CTVinfected trees by the Central California Tristeza Eradication Agency (CCTEA) (9).
No recent studies have been conducted on the transmissibility of CTV in central California. Dodds and Gumpf (9) reported a high incidence of CTV-infected trees in parts of central California in 1990 and suspected that rates of aphid transmission were high. In 1994, Dodds (8) estimated the number of CTV-infected trees in Fresno, Tulare, and Kern Counties and projected the time and cost required for finding and removing these trees. Despite this information, growers in the West Fresno Pest Control District and the Tulare County Pest Control District, which represent $45 \%(44,100$ ha) of the acreage in central California, withdrew from the eradication program between 1995 and 1996 and no longer remove infected trees from their groves. In contrast, growers in the Pest Control Districts of Central Valley, South Tulare County, and Kern County continue to participate in the CTV eradication program (Fig. 1).

We conducted this study to assess the level of infection that has resulted from allowing CTV-infected trees to remain and to determine the aphid transmissibility and molecular genotype of CTV isolates currently being spread in central California.

\section{MATERIALS AND METHODS}

Plot locations. Plots were established in two locations along the citrus belt in the eastern San Joaquin Valley which Gottwald et al. (18) had described as being foci of CTV infection (Fig. 1). These foci were attributed to planting of infected trees prior to the 1960 s and natural spread by aphid vectors coupled with temporary or permanent stoppage of CTV eradication efforts. Plots S1 and S2 were adjacent plots approximately $3 \mathrm{~km}$ south of adjacent plots S3 and S4; are all located near Strathmore in Tulare County, where CTVinfected trees are no longer being removed. Plots S1, S2, and S3 were located within navel orange groves 20 to 40 years in age (Table 1). Plot S4 was located in a young Fukumoto navel grove planted in 1997.

The second location was in Kern County in a CTV eradication district; hence, we were able to monitor only one small plot, McFarland 1 (M1) (Fig. 1). The plot was located within a grove planted in 1994 and was selected because it was next to a citrus field that, in 1994, had a CTV infection level of $67.7 \%$. This incidence was due to planting of some CTV-infected trees and litigation that temporarily blocked eradica- 
tion of these trees. Several other adjacent groves had CTV incidence ranging from 14 to $43 \%$. Subsequently, these groves were completely removed and replanted with healthy citrus trees. During this period, all trees in this area were surveyed annually for the presence of CTV by the CCTEA. Trees that tested positive for CTV were removed as soon as possible. In 1998, our initial survey in 1998 of the M1 plot indicated that no infected trees were present.

To determine whether virus incidence found in the M1 plot was indicative of the region, an estimate of CTV incidence in an area of $6.5 \mathrm{~km}^{2}$ (727 ha) was conducted (Fig. 2). This area included approximately
211,150 citrus trees in 99 groves situated immediately southeast of the M1 plot.

Survey methods. The small plots ranged in size from 208 to 442 trees and ranged in tree age from 1 to over 40 years (Table 1). Leaf samples were collected from all plot trees and processed individually. Specifically, two leaves each from new shoots from the north, south, east, and west quadrant of each tree (total of eight leaves) were harvested and the petiole portion excised for serology. Annual samples were taken from 1997 to 2002 .

Sampling in the $6.5 \mathrm{~km}^{2}$ area of citrus (Fig. 2) was accomplished using a system modified from the hierarchical bulk sampling (HS) method developed by Hughes and Gottwald (24) for estimating disease incidence. Our method reduced the number of samples taken per grove to only the center group of 400 trees and was referred to as the subplot HS (40) (Fig. 2, insert). The rationale for the subplot HS was to sample as many contiguous production units in a uniform manner to provide an estimate of infection levels over a larger area with minimal labor. Samples collected with the HS method combined leaf tissue from four adjacent trees as one sample for assay. These samples were collected annually from 2001 to 2003 during April and May when CTV titer is high. All tissue sampled was dried with silica gel as described by Garnsey et al. (11) and stored at

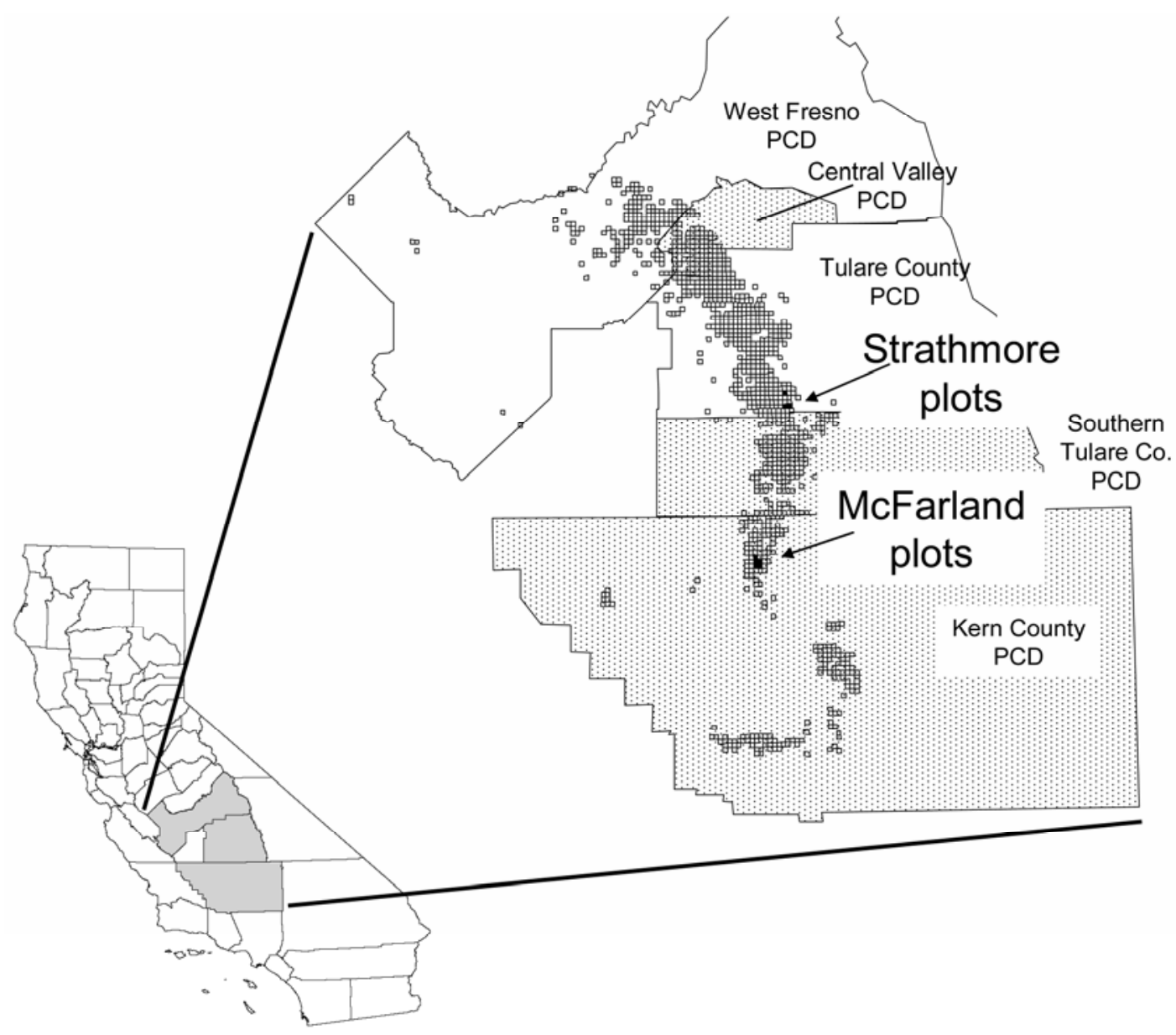

Fig. 1. Map of the citrus production area of central California and the location of Strathmore plots (S1, S2, S3, and S4) in the Tulare County Pest Control District (PCD) and the McFarland plot (M1) in the Kern County PCD. Each square represents $1.61 \mathrm{~km}^{2}(1 \mathrm{mile})$ in which a commercial grove of 25 or more citrus trees are planted. Black squares show actual plot location. Districts where Citrus tristeza virus (CTV)-infected trees continue to be removed are shaded.

Table 1. Description of the citrus plots in Strathmore and McFarland ${ }^{\mathrm{a}}$

\begin{tabular}{llllllll}
\hline Plot $^{\mathbf{b}}$ & Location & Pest control district & Eradication & Cultivar & Rootstock & Year planted & No. of trees in plot \\
\hline Analysis 1 & & & & & & & \\
S1 & Strathmore & Tulare County & No & Frost navel & Cleo & ca. 1960 & 252 \\
S2 & Strathmore & Tulare County & No & Frost navel & Troyer & ca. 1960 & ca. 1980 \\
S3 & Strathmore & Tulare County & No & Fisher navel & Troyer & 255 \\
Analysis 2 & & & No & Fukumoto navel & Carrizo & 1997 & 224 \\
S4 & Strathmore & Tulare County & Yes & Fukumoto navel & Troyer & 1994 & 442 \\
M1 & McFarland & Kern County & & &
\end{tabular}

a Each plot size was at least 16 rows by 14 trees.

b Analysis 1 sampled from 1997 to 2002 (6 years) and analysis 2 sampled from 1998 to 2002 (4 years). 
room temperature until serological tests were performed.

Maintenance of CTV isolates. In all, $20 \mathrm{CTV}$ isolates were collected from the McFarland plots and 16 isolates were collected from the Strathmore plots (Table 2). Isolates were collected following annual surveys for CTV and typically were from newly infected trees from the previous annual survey. Hence, these isolates represented those that were currently being spread by local aphid vectors. The isolates were graft inoculated onto Madam Vinous sweet orange (Citrus sinensis (L.)) seedlings from 6 to $15 \mathrm{~cm}$ above the soil line in the greenhouse by inserting one blind bud and two young leaf pieces from the infected field source per plant. The virus was allowed to incubate in the plant for 60 to 90 days before testing for systemic infection. These virus source plants then remained in the greenhouse indefinitely. The greenhouse was maintained at 15 to $27^{\circ} \mathrm{C}$ by evaporative coolers and Modine heaters. Plants received supplemental lighting with high-pressure sodium lamps directly above the plant bench from October through March.

Aphid colony maintenance. A colony of cotton aphids was established from a naturally infested cotton field located next to citrus groves approximately $13 \mathrm{~km}$ east of Sanger (Fresno County), CA. The colony was established on cotton seedlings, Gossypium hirsutum var. Maxxa (seed obtained from the University of California Shafter Research and Extension Center, Shafter) and maintained in an insectary at $21^{\circ} \mathrm{C}$ with a regime of $16 \mathrm{~h}$ of light and $8 \mathrm{~h}$ of dark using high-output fluorescent lights supplemented with $25-\mathrm{W}$ tungsten bulbs.

Vector transmission. The CTV isolates were tested for transmissibility by the cotton aphid using procedures previously described by Yokomi and Garnsey (38). For virus acquisition, leaves infested with all apterous life stages of the aphid were placed in a cage over a virus-infected Madam Vinous plant. The acquisition ac- cess period (AAP) was $24 \mathrm{~h}$ and was conducted in a growth chamber with continuous light at $24^{\circ} \mathrm{C}$. The inoculation access period (IAP) was determined by placing virus-infected tissue infested with 5 to 10 viruliferous aphids into a small cage covering healthy Mexican lime seedlings ranging from 6 to $12 \mathrm{~cm}$ tall with young flush for $24 \mathrm{~h}$ at $24^{\circ} \mathrm{C}$. In all, 71 to 100 receptor plants (replications) were used for each transmission test. Following the IAP, aphids on receptor plants were counted and then eliminated by insecticide treatment.

Serology. All field and greenhouse plant samples were diluted 1:20 (wt/vol) in PBST buffer $(0.01 \mathrm{M}$ sodium phosphate, $\mathrm{pH} 7.4,0.14 \mathrm{M} \mathrm{NaCl}, 2.68 \mathrm{mM} \mathrm{KCl}$, $0.04 \%$ Tween 20 ) containing $+2 \%$ polyvinylpyrrolidone 10 and ground for $15 \mathrm{~s}$ in a Kleco Tissue Homogenizer (Garcia Manufacturing, Visalia, CA.). Serology was performed using the double-antibody sandwich indirect (DASI) enzyme-linked immunosorbent assay (ELISA). Polyclonal antibodies made to CTV (kindly provided

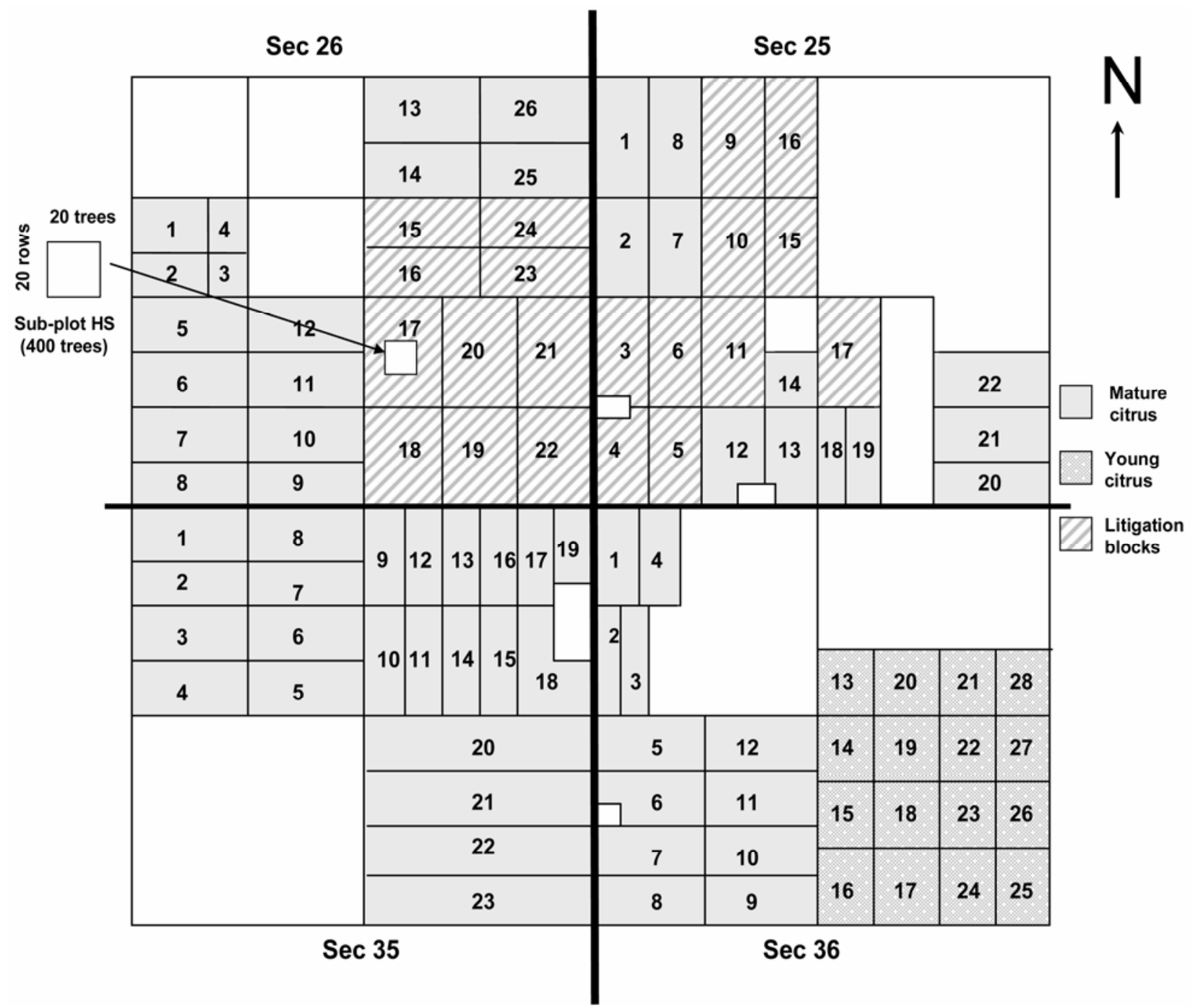

Fig. 2. Map of a 1,036-ha area $\left(6.4 \mathrm{~km}^{2}\right)$ near McFarland, Calif. The map is divided into four sections (25, 26, 35, and 36), each showing individual blocks of citrus (numbered and shaded). Citrus fields where litigation temporarily halted Citrus tristeza virus (CTV) control measures from 1995 to 2001 are also shown. Young citrus planted during the survey period are shown. The insert shows a sample area of 20 rows by 20 trees (= 400 trees) in the middle of each block where the subplot hierarchical bulk sampling (HS) was taken. Each block of citrus sampled ranged from 4 to 16 ha in size. 
by the Citrus Clonal Protection Program [CCPP], Department of Plant Pathology, University of California, Riverside) were used for the immunoassays. The second or detecting antiserum was that made to the expressed CTV capsid protein (p25 gene) and produced in rabbits (29). ELISA was performed essentially as described by Dodds (8) using alkaline phosphatase as the enzyme. Immunoassays of greenhouse plants were conducted from tissue homogenates of $0.25 \mathrm{~g}$ wet weight of bark or leaf midveins per plant. Isolates also were tested for reactivity against the CTV strain-discriminating monoclonal antibody MCA 13 (31) by DASI-ELISA. MCA13 was obtained from Nokomis Corp, Intercession City, FL.

Receptor plants from vector tests were examined for symptoms 6 to 8 weeks post inoculation and samples subsequently were collected for serology. CTV infection was confirmed by DASI-ELISA as described above. Infection also was detected by the use of the direct tissue blot immunoassay (DTBIA) (13) using CTV rabbit polyclonal antiserum 1212 made from purified virions from an Australian stem-pitting isolate of CTV obtained from the Department of Plant Pathology, University of Florida, Gainesville. DTBIA was found to be as fast and reliable as DASI-ELISA for the detection of CTV in young seedlings receptor plants.

CTV molecular evaluation. The molecular genotype of test isolates was determined by the multiple molecular marker method developed by Hilf and Garnsey $(21,22)$. This system uses sequencespecific primers from nonconserved re-

Table 2. Comparison of Aphis gossypii (cotton biotype) transmission rates of Citrus tristeza virus (CTV) isolates collected from the McFarland plots in a CTV eradication district compared with the Strathmore plots in a CTV noneradication district

\begin{tabular}{|c|c|c|c|c|c|}
\hline \multirow[b]{2}{*}{ Isolate } & \multirow[b]{2}{*}{ Location } & \multicolumn{4}{|c|}{ Vector transmission ${ }^{a}$} \\
\hline & & Date & No. infected & No. exposed & Transmission (\%) \\
\hline \multicolumn{6}{|c|}{ McFarland area ${ }^{b}$} \\
\hline P81 & $12 \mathrm{~B}$ & January & 52 & 84 & 61.9 \\
\hline $\mathrm{P} 28$ & 514 & April & 47 & 98 & 48 \\
\hline $\mathrm{P} 26$ & 504 & May & 43 & 98 & 43.9 \\
\hline P74 & $12 \mathrm{~B}$ & January & 33 & 84 & 39.3 \\
\hline P83 & $12 \mathrm{~B}$ & December & 20 & 84 & 23.8 \\
\hline P89 & $13 \mathrm{~A}$ & December & 20 & 84 & 23.8 \\
\hline $\mathrm{P} 25$ & 514 & September & 22 & 100 & 22 \\
\hline P77 & $12 \mathrm{~B}$ & December & 18 & 84 & 21.4 \\
\hline $\mathrm{P} 21$ & 514 & July & 16 & 84 & 19 \\
\hline $\mathrm{P} 92$ & $13 \mathrm{~A}$ & June & 10 & 84 & 11.9 \\
\hline P86 & $3 \mathrm{~B}$ & November & 4 & 84 & 4.8 \\
\hline P84 & $12 \mathrm{~A}$ & February & 4 & 84 & 4.8 \\
\hline P88 & $13 \mathrm{~A}$ & July & 4 & 84 & 4.8 \\
\hline $\mathrm{P} 23$ & 514 & January & 4 & 98 & 4.1 \\
\hline P90 & $13 \mathrm{~A}$ & July & 3 & 84 & 3.6 \\
\hline P51 & 514 & September & 3 & 99 & 3 \\
\hline P67 & $13 \mathrm{~B}$ & January & 2 & 71 & 2.8 \\
\hline P91 & $13 \mathrm{~A}$ & February & 2 & 84 & 2.4 \\
\hline P70 & $12 \mathrm{~B}$ & June & 1 & 84 & 1.2 \\
\hline P52 & 514 & August & 0 & 84 & 0 \\
\hline Overall $^{\mathrm{c}}$ & $\ldots$ & $\ldots$ & 308 & 1,740 & $17.7 * *$ \\
\hline \multicolumn{6}{|c|}{ Strathmore area ${ }^{\mathrm{d}}$} \\
\hline P3 & 502 & November & 21 & 93 & 22.6 \\
\hline P7 & 502 & May & 17 & 98 & 17.3 \\
\hline P16 & 508 & April & 16 & 94 & 17 \\
\hline $\mathrm{P} 10$ & 502 & July & 6 & 84 & 7.1 \\
\hline P5 & 502 & November & 4 & 82 & 4.9 \\
\hline $\mathrm{P} 4$ & 502 & November & 3 & 90 & 3 \\
\hline P6 & 502 & October & 2 & 84 & 2.4 \\
\hline $\mathrm{P} 1$ & 506 & November & 2 & 92 & 2.2 \\
\hline P17 & 508 & May & 2 & 95 & 2.1 \\
\hline P9 & 502 & May & 2 & 98 & 2 \\
\hline $\mathrm{P} 20$ & Bri-1 & June & 1 & 84 & 1.2 \\
\hline P14 & 503 & January & 1 & 98 & 1 \\
\hline P18 & 509 & January & 1 & 98 & 1 \\
\hline P30 & 502 & May & 1 & 98 & 1 \\
\hline P19 & Bri-2 & January & 0 & 75 & 0 \\
\hline P15 & 508 & May & 0 & 98 & 0 \\
\hline Overall $^{\mathrm{c}}$ & $\ldots$ & $\ldots$ & 79 & 1,461 & $5.4 * *$ \\
\hline
\end{tabular}

${ }^{a}$ For the transmission tests, Madam Vinous sweet orange was the CTV donor plant, Mexican lime seedlings were the receptor plant, virus acquisition access and inoculation access periods were $24 \mathrm{~h}$ each, and 5 to 10 aphids per receptor plant was used. Shown are date transmitted, number of plants infected by CTV, number of plants exposed, and percent transmission.

${ }^{\mathrm{b}}$ CTV isolates collected from different plots in a area of approximately $5 \mathrm{~km}^{2}$.

c Overall rate of transmission per area. ${ }^{* *}=$ significantly different $(P<0.001)$.

${ }^{\mathrm{d}}$ CTV isolates collected from different plots in a area of approximately $10 \mathrm{~km}^{2}$. gions including the $5^{\prime}$-UTR, K17, and POL of the virus genome (23) from four different CTV strains (Florida isolates T3, T30, and T36 and Israel isolate VT). The molecular procedures used were adapted from Hilf et al. (23) and are described as follows. Two hundred microliters of a 1:1,000 dilution in coating buffer $\left(0.02 \mathrm{M} \mathrm{Na}_{2} \mathrm{CO}_{3}\right.$ $0.03 \mathrm{M} \mathrm{NaHCO}_{3}$, pH 9.6) of purified immunoglobulin $\mathrm{G}$ purified from the 1212 polyclonal antiserum was added to a $0.2-$ $\mathrm{ml}$ thin-walled polymerase chain reaction (PCR) tube and incubated for $24 \mathrm{~h}$ at $4^{\circ} \mathrm{C}$. The tubes were washed three times with PBST and then $200 \mu \mathrm{l}$ of sap expressed from $0.25 \mathrm{~g}$ of fresh bark of infected Madam Vinous and diluted 1:20 in PBST was added to the PCR tube and incubated for $24 \mathrm{~h}$ at $4^{\circ} \mathrm{C}$. First-strand cDNA was prepared from immunocaptured virions by adding $20 \mu \mathrm{l}$ of a mixture of $50 \mathrm{mM}$ Tris$\mathrm{HCl}, \mathrm{pH} 8.3 ; 3 \mathrm{mM} \mathrm{MgCl} 2 ; 75 \mathrm{mM} \mathrm{KCl}$; $10 \mathrm{mM}$ dithiothreitol; $0.5 \mathrm{mM}$ each dNTPs; 62.5 units/ml of absorbance at 260 $\mathrm{nm}$ of random hexamers (Hexanucleotide mix, Roche Molecular Biochemicals); 20 units of RNasin (Promega Corp., Madison, WI); and 200 units of MMLV-RT (Promega), followed by incubation at $37^{\circ} \mathrm{C}$ for $45 \mathrm{~min}$. The reaction then was heated at $65^{\circ} \mathrm{C}$ for $10 \mathrm{~min}$, after which $40 \mu \mathrm{l}$ of sterile water was added to each reaction. Reactions not used immediately were stored at $-20^{\circ} \mathrm{C}$.

Twelve sequence-specific primers described previously $(21,22)$ were used in PCR reactions. cDNA $(5 \mu \mathrm{l})$ was amplified in a $20-\mu$ l reaction volume containing 0.2 $\mathrm{mM}$ each dNTP, $1.5 \mathrm{mM} \mathrm{MgCl}_{2}, 0.2 \mu \mathrm{M}$ each primer, and 0.5 units of Taq DNA polymerase (Promega Corp.) for 30 cycles of $30 \mathrm{~s}$ at $94^{\circ} \mathrm{C}, 60 \mathrm{~s}$ at $56^{\circ} \mathrm{C}$, and $90 \mathrm{~s}$ at $72^{\circ} \mathrm{C}$ followed by $5 \mathrm{~min}$ at $72^{\circ} \mathrm{C}$. PCR products were analyzed on $1.0 \%$ agarose gels and stained with $1 \%$ ethidium bromide in deionized water. The T3, T30, T36, and VT isolates kindly provided as lyophilized samples by T. Paul were included in our tests as controls.

Statistical analysis. The percentage of CTV-infected trees in plots S1, S2, S3, S4, and M1 were analyzed as a discrete effect per year and as a continuous linear effect along with their interaction. Slopes are presented along with their $95 \%$ confidence limits. Analysis of mature groves and the young grove were conducted separately. Estimates of CTV-infected trees from the $6.5-\mathrm{km}^{2}$ area were analyzed by a generalized linear model approach with a logit link function for the binomial response of number infected per number of trees sampled. The model included plot, year, and the interaction. Because the interaction was not significant, least squares means and $95 \%$ confidence limits (CL) transformed back to incidences are presented (26).

Vector transmissibility between CTV isolates from the Strathmore area and the 
McFarland area was subjected to a oneway analysis of variance model between and within each area and the data was transformed by a square root of percent transmission to normalize the data. Proc mixed analysis (26) was used to incorporate the existing heterogeneity of variance in the model. Area means and their 95\% confidence intervals were transformed back to the original units of measurement and presented (26).

\section{RESULTS}

Field surveys. The incidence of CTV in mature navel trees in the Strathmore plots from 1997 to 2002 is shown in Figure 3A. During this period, incidence of CTV in the S1 plot increased from 24.2 to $42.1 \%$, plot S2 increased from 22.4 to $32.2 \%$, and S3 increased from 17.9 to $24.5 \%$. Although it was expected that the rate of increase would be exponential due to the high incidence of CTV infection, the annual rates of new infections followed a more linear pattern. The slope (including the lower and upper 95\% CL) of $\mathrm{S} 1$ was $b=3.85$ (3.12, 4.59), S2 was $b=2.11(1.37,2.84)$, and S3 was $b=1.48(0.75,2.22)$. The slope of $\mathrm{S} 1$ was significantly higher than that of S2 or S3 $(P<0.001)$. Trees in S1 were on Cleopatra Mandarin rootstock, whereas S2 and S3 were on Troyer rootstock.

A separate analysis of CTV incidence was performed on the young Fukumoto navels trees in plots S4 and M1 and is shown in Figure 3B. S4 was planted on Carrizo citrange rootstock and M1 on Troyer rootstock. CTV incidence in S4 was evaluated from 1998 to 2002 and increased from 0 to $6.3 \%$, with $b=1.67$ $(0.83,2.52)$. Incidence in M1, evaluated between 1998 and 2001 went from 0 to $5 \%$ with $b=1.45(0.82,2.04)$. The annual increase in CTV infections in the youngtree plots also followed a linear pattern; however, the slopes of S4 and M1 were not significantly different by regression analysis. Hence, the rate of increase in the plot at McFarland in the eradication district was the same as that in the Strathmore plot located in an area where incidence of CTV infection in mature trees exceeded $25 \%$.

Estimates of CTV incidence from data collected during a 3-year period in the 6.5$\mathrm{km}^{2}$ area southeast of the McFarland plots showed that only low levels of infection existed (Table 3). The annual increase in CTV infection per section showed no interactions between incidence and year; hence, the estimated incidence per section was averaged over the duration of the survey. The estimated incidence (and lower and upper 95\% CL) of CTV was 0.643 (0.44 and 0.938), 0.684 (0.485 and 0.964), $0.189(0.093$ and 0.383$)$, and $0.089 \%$ ( 0.089 and $0.367 \%)$ for sections $25,26,35$, and 36 , respectively. The infection levels for sections 25 and 26 were statistically higher than those for sections 35 and 36 ( $P$ $<0.001)$. This correlated with the conse- quences of litigation that prevented the removal of CTV-infected trees from 1997 until 2002 in 9 of 26 groves in McFarland section 25 and 10 of 22 groves in section 26 (Fig. 2). These data indicate that CTV suppression still was being achieved despite a temporary interruption of some local eradication efforts and finding natural spread of CTV occurring in the nearby M1 plot.

Aphid transmission. Vector transmission results of the $36 \mathrm{CTV}$ isolates from the McFarland and Strathmore plots are shown in Table 2. The CTV isolates were separated into three classes of transmissibility by the cotton aphid: low $=0$ to 5 , intermediate $=7$ to 24 , and high $=30$ to
$62 \%$. More isolates in the intermediate and high transmission categories were found in the McFarland versus the Strathmore plots. A generalized comparison of transmissibility between the two areas was made by combining individual isolates from each area and calculating the average transmission rate (lower and upper 95\% CL) per area. The average transmission rate of all isolates from the McFarland plots was $17.7 \%$ (9.2 and $27.7 \%$ ) whereas that of the Strathmore isolates was $5.4 \%$ (3.5 and $10.7 \%)$. These differences were statistically different $(P<0.001)$. Even though the virus incidence of the Strathmore area was high, it is unknown if this is an indication that there was less diversity of trans-
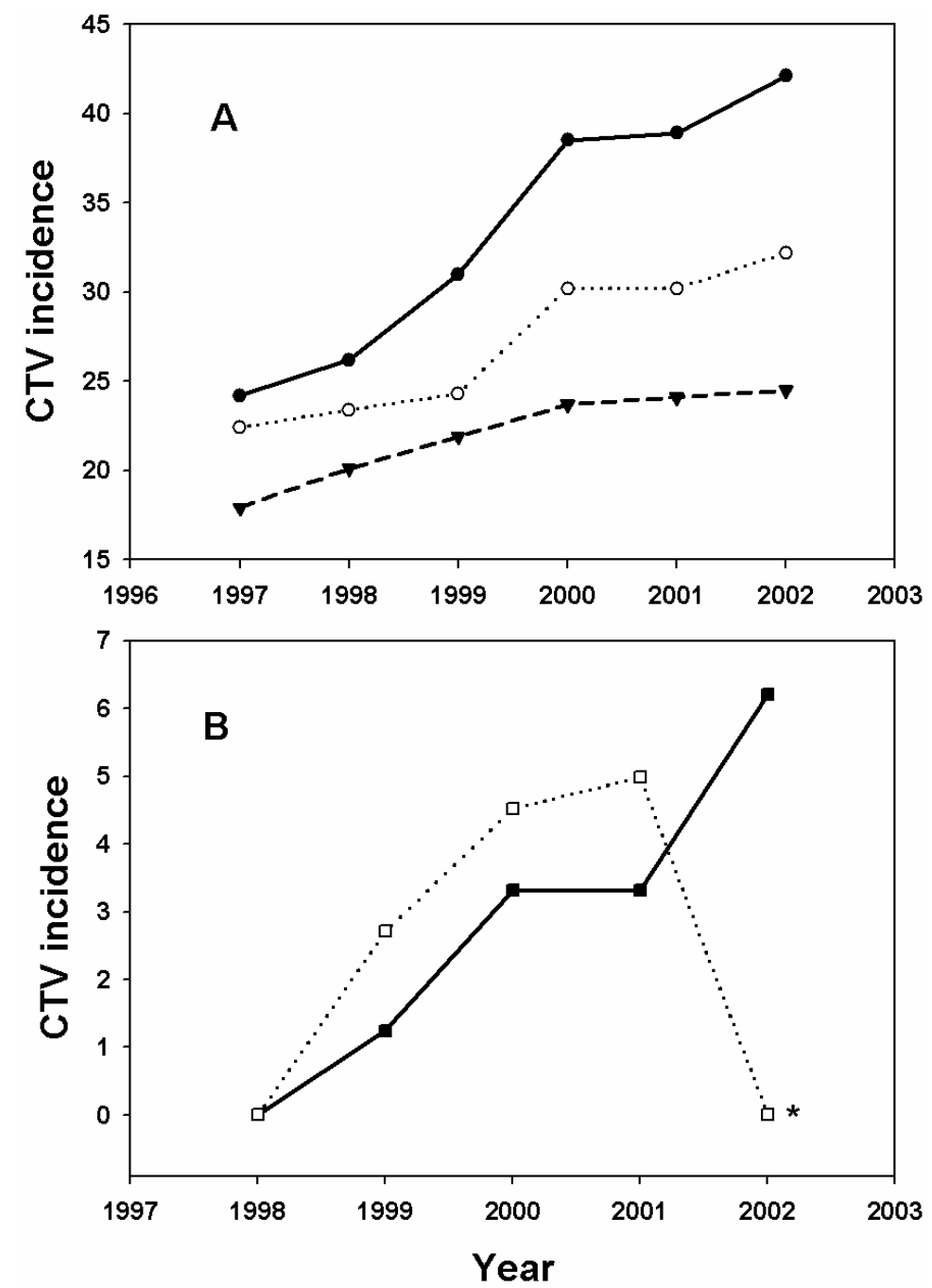

Fig. 3. Increase in Citrus tristeza virus (CTV) incidence in citrus plots. Incidence based on an individual tree survey of a block of trees approximately 16 rows by 25 trees within a row. A, Mature citrus from plots located in near Strathmore (Tulare County) where CTV eradication efforts have ceased. $\bullet=$ S1 plot of Frost nucellar navel trees on Cleopatera mandarin rootstock planted ca. 1960 (14 rows by 18 trees); $O=$ S2 plot of Frost nucellar navel trees on Troyer rootstock planted ca. 1960 (17 rows by 15 trees); $\boldsymbol{\Lambda}=\mathrm{S} 3$ plot of Fisher navel trees on Troyer rootstock planted ca. 1980 (16 rows by 14 trees). Slope $(b)$ and $95 \%$ confidence limits (CL) of S1 is $b=3.85(3.12,4.59)$; S2 $b=2.11(1.37,2.84)$; and $\mathrm{S} 3 b=1.48(0.75,2.22)$. Slope $\mathrm{S} 1$ is statistically different from that of S2 and S3 $(P<0.001)$. B, CTV increase in young plantings of Fukumoto navel. $\mathbf{\square}=$ S4 plot on Carrizo rootstock planted in 1997 (15 rows by 16 trees) near Strathmore where CTV-infected trees are not removed. $\square=$ M1 plot on Troyer rootstock planted in 1994 (17 rows by 26 trees) near McFarland that is in the CTV-eradication district in Kern County. Slope $(b)$ and $95 \%$ CL of S4 is $b=1.67(0.83,2.52)$; M1 $b=1.45(0.85,2.04)$. Slopes of S4 and M1 were not significantly different $(P=0.05)$. * Indicates that all CTV-infected trees in plot were removed. 
missible CTV isolates in eradication districts. The vector efficiency per isolate was found to be a consistent over time as long as virus incubation temperature was maintained between 15 and $25^{\circ} \mathrm{C}$.

Genotype evaluation and MCA13 reactivity. The molecular genotype of the isolates studied was found to be identical to the T30 mild isolate from Florida (GenBank accession number AF260651) based on the PCR products obtained from the sequence-specific primers. Amplicons of the expected size were obtained from the T30, T36, T3, and VT isolate controls, indicating that our test conditions were appropriate. None of our field isolates reacted in ELISA tests with the MCA13 monoclonal antibody, whereas the standard control isolates T36, T3, and VT reacted with MCA13 as expected. Furthermore, none of our isolates induced any appreciable stem-pitting symptoms after 6 months or more in the Madam Vinous source plants in the greenhouse.

\section{DISCUSSION}

CTV incidence was found to range between 17 and $42 \%$ in mature citrus plots in Strathmore, and annual CTV incidence in a newly planted grove in the same area increased from 0 to $6.3 \%$ within 4 years. The Strathmore plots were located in the Tulare County Pest Control District, which stopped eradicating CTV-infected trees in 1996. During our survey, the annual increase in infected trees in the plots was more linear than exponential. Gottwald et al. (14) reported a similar linear pattern of CTV incidence in several plots in Spain. In contrast, a logistic increase in the rate of CTV decline was reported in California (28) and Florida (12) in an A. gossypiiCTV pathosystem. These latter reports, however, were based on symptom expression of quick decline on sour orange rootstock. The collapse of citrus trees due to CTV is correlated to infection by a decline strain of CTV and an associated pathology at interface of the sour orange rootstock and the scion (35). Thus, the onset of symptoms depends on the utilization of starch reserves from the roots relative to the growth demands of the tree (e.g., fruit maturation) and is influenced by weather (e.g., drought or excessive rainfall) and horticultural care. Therefore, the presence of CTV in a tree should be determined by a pathogen detection method such as ELISA rather than by symptom expression. This recommendation is supported by evidence that many CTV isolates are mild and remain symptomless in tolerant citrus varieties (5).

Using ELISA, Gottwald et al. $(15,17)$ found that initial CTV infection in a citrus plots in an A. gossypii-CTV pathosystem often was random from sources outside the plot and that secondary spread occurred over short distances following the nearestneighbor pattern. The generally low and linear annual rate of increase observed in our plots suggested that vector populations developed outside of the citrus plots and transmitted the virus as migrants. In California, selective pesticides which are less toxic to natural enemies typically are applied to citrus in spring and early summer for thrips and mite control. Under these practices, aphid populations are held under control and very few aphid colonies were observed in our field plots. However, further surveys are needed to determine whether logistic increase in CTV incidence will occur in our plots.

The rate of new infections in the young Fukumoto navel plot in the McFarland plots was unexpected. This area was located in the Kern County Pest Control District which continues an active CTV eradication program. Because this plot was located adjacent to fields where CTV infection once was high and extensive eradication of CTV-infected trees has occurred since 1994, our data indicated that inoculum sources and associated vector activity still were present in this area. Gottwald et al. (16) reported that at least 6 months to 2 years of post-infection time is required before the CTV titer in a field tree reaches thresholds high enough to be detectable by ELISA. During this period, aphids are capable of acquiring and transmitting the virus.

Despite the observed localized spread of CTV in the McFarland plot, the low level of CTV-infected trees estimated in the 6.5$\mathrm{km}^{2}$ area indicated that the eradication program was still suppressing CTV. This evidence is consistent with results of surveys conducted by the CCTEA (4).

A. gossypii is cosmopolitan in distribution and extremely polyphagous. It is an important pest of citrus, cotton, and many vegetable and ornamental crops (2). It is not surprising, therefore, that biotypes (plant-adapted races) of A. gossypii exist. Swift (36) demonstrated that A. gossypii populations collected from cotton, squash, cantaloupe, and citrus in California could be grouped as either a cotton biotype or a cucurbit biotype. Recently, VanlerbergheMasutti and Chavigny (37) have presented evidence for genetic differences within species of A. gossypii collected from cucurbit and noncucurbit hosts based on random amplified polymorphic DNA fingerprints.

Most of the previous CTV transmission tests were conducted with the melon aphid $(2,6,7,27,32-34)$ reared on cucurbits. In Florida, however, CTV transmission tests were conducted by a noncucurbit biotype because the aphid was reared on kenaf (Hibiscus cannabinus), okra (Abelmoschus esculentus), or hibiscus (Hibiscus rosasinensis) $(30,38)$. Our vector data agree with those from Florida and indicate that the cotton aphid (or noncucurbit biotype) is an efficient vector of CTV and that some local isolates in central California are highly transmissible by this biotype.

A consistent level of CTV transmission was obtained over time for each isolate when the greenhouse temperatures were

Table 3. Comparison of estimated Citrus tristeza virus (CTV) incidence in a $6.5-\mathrm{km}^{2}$ area in a CTV eradication district based on a subplot hierarchical bulk sampling scheme

\begin{tabular}{|c|c|c|c|c|c|c|c|c|c|}
\hline \multirow[b]{2}{*}{ Section $^{c}$} & \multirow[b]{2}{*}{ No. of fields ${ }^{d}$} & \multirow[b]{2}{*}{ Area (ha) $)^{\mathrm{e}}$} & \multirow[b]{2}{*}{ No. of trees ${ }^{f}$} & \multicolumn{3}{|c|}{ Estimated CTV incidence/year ${ }^{\mathrm{a}}$} & \multicolumn{3}{|c|}{ Overall estimated CTV incidence $^{b}$} \\
\hline & & & & 2001 & 2002 & 2003 & Infection (\%) & Lower CL & Upper CL \\
\hline 25 & 22 & 157.8 & 44,681 & 0.596 & 0.735 & 0.605 & $0.643^{*}$ & 0.440 & 0.938 \\
\hline 26 & 26 & 210.5 & 51,470 & 0.976 & 0.739 & 0.402 & $0.684 *$ & 0.485 & 0.964 \\
\hline 35 & 23 & 190.3 & 51,055 & 0.131 & 0.394 & 0.131 & 0.189 & 0.093 & 0.383 \\
\hline 36 & 28 & 168.6 & 63,938 & 0.323 & 0.143 & 0.179 & 0.181 & 0.089 & 0.367 \\
\hline Totals & 99 & 727.2 & 211,144 & $\ldots$ & $\ldots$ & $\ldots$ & $\ldots$ & $\ldots$ & $\ldots$ \\
\hline
\end{tabular}

${ }^{a}$ Estimate of CTV incidence calculated by model developed by Hughes and Gottwald (24). Plots within each section were treated as a replication for statistical analysis. Because no statistically significant interactions between plot x year were found among plots, estimated differences between CTV incidence in the plots could be averaged over all three years.

${ }^{\mathrm{b}} \mathrm{CL}=$ confidence limits within which $95 \%$ of the data occurred; * indicates that CTV incidence in sections 25 and 26 were statistically different than that of sections 35 and $36(P<0.05)$

${ }^{\mathrm{c}}$ Entire sample area was 1,037 ha which contained 727 ha of citrus. This area was divided into four equal and adjacent 259-ha sections and labeled section $25,26,35$, and 36 .

${ }^{\mathrm{d}}$ Number of citrus fields. Each citrus plot varied in size from 2.0 to 16.2 ha and a subplot constituted a group of 400 trees in the center of each block. Twenty composite samples were collected from each group of four trees (quadrat) per plot using the hierarchical bulk sampling pattern (40). Actual total number of trees sampled $=9,900$ per year.

e Total amount of citrus area.

${ }^{\mathrm{f}}$ Number of trees in the section. 
maintained between 15 and $27^{\circ} \mathrm{C}$ and high heat conditions during the test period were avoided. Bar Joseph and Loebenstein (1) have shown that CTV source plants maintained at 22 versus $31^{\circ} \mathrm{C}$ resulted in significantly higher transmission rates by $A$. gossypii. This is relevant for CTV transmission in the San Joaquin Valley because maximum temperatures $\geq 31^{\circ} \mathrm{C}$ are common from June through September.

CTV isolates from the plots had a single genotype of CTV identical to the T30 mild isolate from Florida. Most CTV isolates from central California characterized by the CCPP have been characterized as mild (5). However, a few isolates were identified that induced mild to moderate stem pitting in sweet orange or grapefruit, as well as some isolates that induced a seedling yellows reaction (5). In this regard, L. Whitendale and A. D. Seymour (personal communication) found that CTV-infected navel trees in the Tulare County Pest Control District increased in productive value initially; however, this was followed by an annual loss of more than $\$ 4$ per tree compared with healthy trees over a 10-year period. The lack of MCA13 reactivity of our test isolates agrees with similar data from the CCTEA and the CCCP (5) which show that most common California isolates do not react with the MCA13 monoclonal antibody.

Hilf and Garnsey (22) evaluated the genotype of a subset of CTV isolates collected from trees in Florida between 1965 and 1998 and found that 51\% (206 of 405 isolates) consisted of the T30 genotype, $32 \%$ had a mixture of T30 and T36 genotypes, $8 \%$ had the T36 genotype, $6.9 \%$ had the VT genotype, and $2 \%$ contained a mixture of VT and T36 genotypes. When $T$. citricida became established in Florida in 1996, the genetic diversity of CTV isolates presumably began to shift toward greater virulence. Halbert et al. (19) reported that MCA13-positive CTV infections increased in south Florida and now are more common than nonreacting MCA13 isolates. They also identified CTV isolates that reacted to molecular probes specific to stem-pitting CTV isolates. This increase in CTV isolate severity presumably is due to the transmission by $T$. citricida. Whether this is because of the abundance of the vector or some unknown synergistic interaction of CTV variants with T. citricida is unknown. However, should $T$. citricida become established in California, a similar increase in CTV virulence over time would be expected.

In summary, CTV levels are now high in some noneradicative areas in central California and isolates occur that are efficiently transmitted by the cotton aphid. In spite of this, CTV continues to be suppressed to low levels by the eradication program in Kern County. The CTV isolates in our plots were symptomless in field trees and did not induce stem pitting in
Madam Vinous plants in the greenhouse. These isolates also had a genotype identical with the Florida mild T30 isolate. By these criteria, the CTV isolates examined were considered to be avirulent at his time. However, the affect of a chromic field infection from such isolates on sweet orange production remains unknown.

\section{ACKNOWLEDGMENTS}

We thank A. Cornett, United States Department of Agriculture-Agricultural Research Service (USDA-ARS), EIDP, Parlier, CA for assistance in maintaining plants, virus and aphid cultures, field sampling, and serology; B. Mackey, USDA-ARS, PWA, Albany, CA for helping with the statistical analysis; G. Montez, University of California Kearney Agricultural Center, Parlier for the map of the citrus-growing region in central California; and $\mathrm{M}$. E. Hilf, USDA-ARS, USHRL, Ft. Pierce, FL for assistance in the genotype analysis of CTV and, with D. Ullman, for critical advice to improve this paper.

\section{LITERATURE CITED}

1. Bar-Joseph, M., and Loebenstein, G. 1973. Effect of strain, source plant, and temperature on transmissibility of citrus tristeza virus by the melon aphid. Phytopathology 63:716-720.

2. Blackman, R. L, and Eastop, V. F. 1985. Aphids on the World's Crops, An Identification Guide. John Wiley \& Sons, Chichester, England

3. Calavan, E. C., Harjung, M. K., Blue, R. L., Roistacher, C. N., Gumpf, D. J., and Moore, P. W. 1980. Natural spread of seedling yellows and sweet orange and grapefruit stem pitting tristeza viruses at the University of California, Riverside. Pages 69-75 in: Proc. 8th Conf. Int. Organ. Citrus Virol. IOCV, Riverside, CA.

4. Central California Tristeza Eradication Agency. 2003. Technical Advisory Committee Report. CCTEA, Tulare, CA.

5. Citrus Clonal Protection Program. 2002. Biocharacterization reactions of California citrus tristeza isolates. University of California, Riverside, Dep. Plant Pathol. Online: http://ccpp.ucr.edu/diseases/ctvisolates.html.

6. Dickson, R. C., Flock, R. A., and Johnson, M. McD. 1951. Insect transmission of citrus quick decline virus. J. Econ. Entomol. 44:172-176.

7. Dickson, R. C., Johnson, M. M., Flock, R. A. and Laird, E. F., Jr. 1956. Flying aphid populations in southern California citrus groves and their relation to the transmission of the tristeza virus. Phytopathology 46:204-210.

8. Dodds, J. A. 1994. Citrus tristeza virus incidence in the Central Valley: progress toward eradication. Citrograph 77(7):12-20.

9. Dodds, J. A., and Gumpf, D. J. 1991. Citrus tristeza virus in central California. Citrograph 76:4-11.

10. Fawcett, H. S., and Wallace, J. M. 1946. Evidence of the virus nature of citrus quick decline. Calif. Citrograph. 32:50, 88, 89.

11. Garnsey, S. M., Gottwald, T. R., and Borbón, J. C. 1996. Rapid dissemination of mild isolates of citrus tristeza virus following introduction of Toxoptera citricida in the Dominican Republic. Pages 92-103 in: Proc. 13th Conf. Int. Organ. Citrus Virol. IOCV, Riverside, CA.

12. Garnsey, S. M., and Jackson, J. L., Jr. 1975. A destructive outbreak of tristeza in central Florida. Proc. Fla. State Hortic. Soc. 88:65-69.

13. Garnsey, S. M., Permar, T. A. Cambra, M., and Henderson, C. T. 1993. Direct tissue blot immunoassay (DTBIA) for detection of citrus tristeza virus (CTV). Pages 39-50 in: Proc. 12th Conf. Int. Organ. Citrus Virol. IOCV, Riverside, CA.

14. Gottwald, T. R., Cambra, M., Moreno, P., Camarasa, E., and Piquer, J. 1996. Spatial and temporal analysis of citrus tristeza virus in eastern Spain. Phytopathology: 86:45-55.

15. Gottwald, T. R., Garnsey, S. M., Cambra, M. Moreno, P., Irey, M., and Borbón, J. 1996. Differential effects of Toxoptera citricida vs. Aphis gossypii on temporal increase and spatial patterns of spread of citrus tristeza. Pages 120-129 in: Proc. 13th Conf. Int. Organ. Citrus Virol. IOCV, Riverside, CA.

16. Gottwald, T. R., Garnsey, S. M., and Riley, T. D. 2002. Latency of systemic infection in young field-grown sweet orange trees following graft-inoculation with citrus tristeza virus. Pages 48-53 in: Proc. 15th Conf. Int. Organ. Citrus Virol. IOCV, Riverside, CA.

17. Gottwald, T. R., Gibson, G., Garnsey, S. M., and Irey, M. 2000. The effect of aphid vector population composition on local and background components of citrus tristeza virus spread. Pages 88-93 in Proc. 14th Conf. Int. Organ. Citrus Virol. IOCV, Riverside, CA.

18. Gottwald, T. R., Polek, M., and Riley, K. M. 2002. History, present incidence, and spatial distribution of citrus tristeza virus in the California Central Valley. Pages 83-96 in: Proc. 15th Conf. Int. Organ. Citrus Virol. IOCV, Riverside, CA.

19. Halbert, S. E., Genc, H., Cevik, B., Brown, L. G., Rosales, I. M., Manjunath, K. L., Pomerinke, M., Davison, D. A., Lee, R. F., and Niblett, C. L. 2004. Distribution and characterization of Citrus tristeza virus in south Florida following establishment of Toxoptera citricida. Plant Dis. 88:935-941.

20. Halma, F. F., Smoyer, K. M., and Schwalm, H. W. 1944. Quick decline associated with sour rootstocks. Calif. Citrogr. 29:245.

21. Hilf, M. E., and Garnsey, S. M. 2000. Characterization and classification of citrus tristeza virus isolates by amplification of multiple molecular markers. Pages 18-27 in: Proc. 14th Conf. Int. Organ. Citrus Virol. IOCV, Riverside, $\mathrm{CA}$.

22. Hilf, M. E., and Garnsey, S. M. 2002. Citrus tristeza virus in Florida: A synthesis of historical and contemporary biological, serological, and genetic data. Pages 13-20 in: Proc. 15th Conf. Int. Organ. Citrus Virol. IOCV, Riverside, CA.

23. Hilf, M. E., Karasev, A. V., Albiach-Marti, M R., Dawson, W. O., and Garnsey, S. M. 1999. Two paths of sequence divergence in the citrus tristeza virus complex. Phytopathology 89:336-342.

24. Hughes G., and Gottwald, T. R. 1998. Survey methods for the assessment of citrus tristeza virus incidence. Phytopathology 88:715-725.

25. Kong, P., Rubio, L., Polek, M., and Falk, B. W. 2000. Population structure and genetic diversity within California citrus tristeza virus (CTV) isolates. Virus Genes 21:139-145.

26. Littell, R. C., Stroup, W. W., and Freund, R. J. 2002. SAS for Linear Models, Fourth ed. SAS Institute Inc., Cary, NC

27. Martinez, A. L., and Wallace, J. M. 1964. Studies on transmission of the virus components of citrus seedling yellows by Aphis gossypii. Plant Dis. Rep. 48:131-133.

28. Nesbitt, R. B. 1963. History of the quick decline of oranges in Orange Co. Sunkist Pest Control Circ. No. 309.

29. Nikolaeva, O. V., Karasev, A. V. Gumpf, D. J., Lee, R. F., and Garnsey, S. M. 1995. Production of polyclonal antisera to the coat protein of citrus tristeza virus expressed in Escherichia coli: Application for immunodiagnosis. Phytopathology 85:691-694.

30. Norman, P. A., and Sutton, R. A. 1969. Efficiency of three colonies of melon aphids as transmitters of tristeza virus. J. Econ. Entomol. 62:968.

31. Permar, T. A., Garnsey, S. M., Gumpf, D. J., and Lee, R. F. 1990. A monoclonal antibody that discriminates strains of citrus tristeza vi- 
rus. Phytopathology 80:224-228.

32. Raccah, B., Loebenstein, G., and Bar-Joseph, M. 1976. Transmission of citrus tristeza virus by the melon aphid. Phytopathology 66:1102-1104.

33. Roistacher, C. N., Bar-Joseph, M., and Gumpf, D. J. 1984. Transmission of tristeza and seedling yellows tristeza by small populations of Aphis gossypii. Plant Dis. 68:494-496.

34. Roistacher, C. N., Nauer, E. M., Kishaba, A., and Calavan, E. C. 1980. Transmission of citrus tristeza virus by Aphis gossypii reflecting changes in virus transmissibility in California. Pages 76-82 in: Proc. 8th Conf. Int. Organ. Citrus Virol. IOCV, Riverside, CA.

35. Schneider, H. 1959. The anatomy of tristeza- virus-induced citrus. Pages 73-84 in: Citrus Virus Disease. J. M. Wallace, ed. University of California, Division of Agricultural Science, Berkeley, CA.

36. Swift, J. E. 1958. Factors influencing the distribution and seasonal abundance of Aphis gossypii Glover in California. Ph.D. dissertation. University of California, Berkeley.

37. Vanlerberghe-Masutti, F., and Chavigny, P. 1998. Host-based genetic differentiation in the aphid Aphis gossypii Glover, evidenced from RAPD fingerprints. Mol. Ecol. 7:905-914.

38. Yokomi, R. K., and Garnsey, S. M. 1987. Transmission of citrus tristeza virus by Aphis gossypii and Aphis citricola in Florida. Phyto- phylactica 19:169-172.

39. Yokomi, R. K., Lastra, R., Stoetzel, M. B., Damsteegt, V. D., Lee, R. F., Garnsey, S. M. Gottwald, T. R., Rocha-Peña, M. A., and Niblett, C. L. 1994. Establishment of the brown citrus aphid (Homoptera: Aphididae) in Central America and the Caribbean Basin and transmission of citrus tristeza virus. J. Econ. Entomol. 87:1078-1085.

40. Yokomi, R. K., Polek, M. Satar, S, and Gottwald, T. R. 2002. An economic sampling protocol for locating citrus tristeza virus reservoirs in a large area. Pages 54-59 in: Proc. 15th Conf. Int. Organ. Citrus Virol. IOCV, Riverside, $\mathrm{CA}$ 